\title{
A STUDY OF THE CARDIOVASCULAR TOXIC EFFECTS OF ZINGIBER OFFICINALE (GINGER) IN ADULT MALE ALBINO RATS AND ITS POSSIBLE MECHANISMS OF ACTION
}

\author{
$\mathcal{B Y}$ \\ Iman A. Elkhishin and Ibrahim A. Awwad* \\ Departments of Forensic Medicine and Clinical Toxicology, Pharmacology*, \\ Faculty of Medicine, Zagazig University
}

\begin{abstract}
Ginger is a world known food plant which is equally reputed for its medicinal properties. The aim of the work is to study the acute and subacute cardiovascular toxicity of ginger in adult male albino rats and its possible mechanisms of action. The in- vivo studies included eighty four adult male albino rats for the acute and subacute toxicity experiments. The rats were divided into 7 groups each one consisted of 12 rats. All rats received ginger orally in saline. Each of the in- vivo studies included 2 control groups, the negative and positive control rats. In the acute toxicity study, rats received ginger in a single dose of $2500 \mathrm{mg} / \mathrm{kg}$. In the subacute toxicity study group VI and VII received ginger in a daily dose of $50 \mathrm{mg} / \mathrm{kg}$ and $500 \mathrm{mg} / \mathrm{kg}$ respectively for 28 days. After 24 hours of the acute toxicity and 28 days of the subacute experiments six rats of each group were used for blood pressure and heart rate recording. The other 6 rats were used for histopathological study of the cardiac tissue. The in- vitro experiments included 6 rabbits each weighing $1.5-2 \mathrm{~kg}$. Ginger $(5 \mathrm{mg} / \mathrm{ml})$ was incubated with the aortic spiral strip of each rabbit to investigate the possible mechanisms of action of Ginger. It was concluded that; single dose of $2500 \mathrm{mg} /$ $\mathrm{kg}$ ginger can be a toxic by causing severe hypotension and bradycardia with induction of prenecrotic changes in cardiac tissue. The administration of ginger in a dose of $50 \mathrm{mg} / \mathrm{kg}$ for 28 days produced bradycaria with waviness in cardiac muscle fibers. Ginger in a dose of $500 \mathrm{mg} / \mathrm{kg}$ produced both hypotension and bradycardia with degenerative changes in cardiac myocyte tissue. The hypotensive and bradycardic effects of ginger may be partially due to induction of vasodilatation by increasing nitric oxide release or synthesis and partially due to a calcium channel blocking effect. Also, a cholino-mimetic effect could be contributed in the cardiovascular effects of ginger. While the In-vitro results revealed that ginger is a partial vasorelaxant as it produced a relaxant effect on rabbit's aortic strip procontracted with phenylephrine, while preincubation with L-nitroarginine methyl ester (L-NAME) significantly attenuated the ginger-induced relaxation indicating that the vasodilator effect of ginger is partially mediated through nitric oxide synthesis or release from L-NAME.
\end{abstract}




\section{INTRODUCTION}

In recent years, there has been a substantial increase in the use of the so-called complementary and alternative therapies including herbs. Regarding the use of herbs for health purposes, patients and physicians usually lack accurate information about safety and efficacy of herbal remedies (Bean, 2002). Ginger (rhizome of Zingiber officinale) has been widely used for centuries in gastrointestinal disorders, particularly dyspepsia. Its calcium antagonist effect may explain its use in hyperactive states of gut- like colic and diarrhea (Ghayur and Gilani, 2005a). Ginger can be consumed as a fresh or dried root and is often prepared in teas, soft drinks (including ales), and breads. No specific dosing studies have been performed; however, most clinical research has used between $250 \mathrm{mg}$ and $1 \mathrm{~g}$ of the powdered root in capsular form, taken one to four times daily. For pregnancy-induced nausea and vomiting, most research studies used 250 mg four times daily. (Borrelli et al., 2005). Ginger might be useful as a potential antitumour agent (Ahmed et al., 2000). Raw ginger possesses hypoglycaemic, hypocholesterolaemic and hypolipidaemic potential. Additionally, it is effective in reversing the diabetic proteinuria observed in the diabetic rats (Al-Amin et al., 2006). Many therapeutic indications in toxicology were reported for ginger in experimental animals and humans. It attenuated malathion induced lipid peroxidation and oxidative stress in rats (Padma et al., 2007). Oil from the rhizome of Zingiber officinale could be useful in preventing chemically induced acute liver injury of carbon tetrachloride (CCl4)) and acetaminophen-induced liver toxicities in rats (Yemitan and Izegbu, 2006). Ginger extract and its constituent's gingerol, shogaol and zingerone were tested for their effect on salmonella typhimurium strains. Gingerol and shogaol were mutagenic while ginger and zingerone were not mutagenic (Nagahushan et al., 1987). In- utero exposure to ginger tea results in increased early embryo loss with increased growth in surviving fetuses (Wilkinson, 2000). Others concluded that when ginger was administered to pregnant rats during the period of organogenesis, it caused neither maternal nor developmental toxicity at daily doses of up to $1000 \mathrm{mg} / \mathrm{kg}$ body weight (Weinder and Sigwart, 2001). Drug interaction has been reported with ginger as it significantly decreased the oral bioavailability of cyclosporine and this interaction occurred at the absorption phase (Chiang et al., 2006). The aim of this work is to study the acute and subacute cardiovascular toxicity of Zingebar officinale (ginger) in adult male albino rats and the possible mechanisms of action.

\section{MATERIAL AND METHODS}

\section{Drugs:}

Ginger powder of dried roots of Zingi- 
ber officinale (Mepaco Co., Egypt), urethane (ethyl carbamate) crystals (Prolabo, Paris), L- nitro- arginine methyl ester hydrochloride (L-NAME), phenylephrine, calcium chloride, potassium chloride (Sigma Co USA).

\section{Animals}

Eighty four adult male albino rats, each weighing $180-200 \mathrm{gm}$. They were raised under strict measures in cages made of galvanized zinc plates and fed on basal food containing all rat's requirements (NRC, 1996), and 6 rabbits each weighing 1.5- $2 \mathrm{~kg}$. Both animals were obtained from the Unite of Laboratory Animals, Faculty of Veterinary Medicine, Zagazig University.

\section{In- vivo experiments :}

The rats were classified into 7 groups each consisted of 12 rats:

\section{Acute toxicity experiment groups I, II and III:}

Group I: received ordinary food and water only, used as a negative control group.

Group II: received $2 \mathrm{ml}$ saline (the vehicle of ginger), used as a positive control.

Group III: received 5 folds the high dose i. e., $2500 \mathrm{mg} / \mathrm{kg}$ (Thomson et al., 2002).
Subacute toxicity experiment groups IV, V, VI and VII:

The subacute toxicity experiment extended for 28 days (Durham et al., 1982; Shingatgeri et al., 2002).

Group IV: received ordinary food and water only, used as a negative control group.

Group V: received $1 \mathrm{ml}$ saline daily orally used as a positive control.

Group VI: received a low dose of ginger $50 \mathrm{mg} / \mathrm{kg}$ daily orally in $1 \mathrm{ml}$ of saline (Thomson et al., 2002).

Group VII: received a high dose of ginger $500 \mathrm{mg} / \mathrm{kg}$ daily orally in $1 \mathrm{ml}$ of saline (Thomson et al., 2002).

\section{Parameters measured :}

\section{Acute toxicity study:}

After 24 hours of induction of ginger toxicity 6 rats of each of the control groups as well as of acutely ginger intoxicated group were subjected to blood pressure and ECG recording according to the method of (Burden et al., 1979). In this method the rats were anaesthetized by i. p. injection of urethane $(1.39 \mathrm{mg} / \mathrm{kg})$ given as $25 \%$ freshly prepared solution (Ghosh, 1971). Arterial blood pressure was measured via an arterial cannula introduced into one carotid artery and connected to pressure transducer "PT 400" that was attached to FC 137 strain gauge coupler of oscillograph 400 MD 4 C (Palmer Bioscience). Lead II ECG was recorded by using an ECG limb cable that was attached to FC 
123 strain gauge of oscillograph. HR/ min was calculated by counting the number of heart cycle $(n)$ per fixed distance of chart paper (e. g. $5 \mathrm{~cm}$ ) with speed of $50 \mathrm{~mm} /$ sec then multiply it by $300 / 5$ (Gay, 1965). The other 6 rats were sacrificed and samples from the heart were taken for histopathological study (Horobin and Bancroft, 1998).

\section{Subacute toxicity study:}

After 28 days, 6 rats of each of the negative and positive control groups as well as of low and high therapeutic doses ginger treatment groups were subjected to blood pressure and heart rate recording as previously mentioned in the acute toxicity study. The other 6 rats were sacrificed and samples from the heart were taken for histopathological study (Horobin and Bancroft, 1998).

\section{In-vitro experiments}

\section{Isolated rabbit's aortic spiral strips:}

Rabbits were sacrificed by cutting the throat. The thoracic aorta was dissected from the surrounding tissues and cut spirally to produce a continuous strip. A strip of $3 \mathrm{~cm}$ length was connected by a thread from below to a fine glass tube through which pure oxygen is passed and from above to a side way writing lever which recorded the contractions of the aortic strip on slowly moving smoked drum (Furchgott, 1960). The tissue was bathed in Kreb's solution with the following compo- sition (mM: Nacl 119, $\mathrm{Kcl} 4.7, \mathrm{Cacl}_{2}$ 2.5, $\mathrm{MgSO}_{4} 1.2, \mathrm{NaHCO}_{3} 25, \mathrm{KH}_{2} \mathrm{PO}_{2}$ 1.2, glucose 5.5) maintained at $37{ }^{\circ} \mathrm{C}$. The preparation was allowed to stabilize for one hour before beginning the study. The aortic strips were pro- contracted with phenylephrine at a concentration of $10 \mu \mathrm{g} / \mathrm{ml}$ and when the contraction reached its maximal level (plateau), ginger was added at a concentration of $5 \mathrm{mg} / \mathrm{ml}$ and its relaxant effect was recorded (Ghosh, 1971). The ginger- induced relaxation (after phenylephrine- induced contraction) was assessed in absence and presence of nitric oxide (NO) synthase inhibitor (L- nitro- arginine methyl ester- L-NAME) at a concentration of $100 \mu \mathrm{M}$ (Colas et al., 2000).

A separate series of experiments were conducted to test the possible Cachannel blocking effect of ginger. After equilibrium with normal Kreb's solution, the aortic strip was incubated for $30 \mathrm{~min}$ utes in high $\mathrm{K}^{+}(60 \mathrm{mM})$ (for induction of de polarization), $\mathrm{Ca}^{2+}$ free medium, then the contractile response to $\mathrm{Cacl}_{2}(1 \mathrm{mM})$ was recorded for 15 minutes in absence and presence of ginger $(5 \mathrm{mg} / \mathrm{ml})$ incubated for 30 minutes (Colas et al., 2000).

The collected data of systolic and diastolic blood pressures, heart rate and the results of the in- vitro study were subjected to statistical analysis using the paired- $t$ test of the SPSS statistical package (version 17) (Sheridan, 2009). 


\section{RESULTS}

\section{Acute toxicity study:}

\section{Blood pressure and heart rate}

There were no significant difference between the positive and negative control groups, $(P>0.05)$ (table 1$)$ (figure 3$)$, so the negative control was used for comparison with ginger treated group.

There were significant difference between the ginger treated group and the negative control group regarding arterial blood pressure and heart rate $(\mathrm{P}<0.0001)$ (table 1) (figure 3).

\section{Histopathological results}

Transverse sections of the left ventricle of the heart of the control rats showed acidophilic cytoplasm and centrally located nuclei with capillaries in between. Transverse section of the left ventricle of ginger treated rats in a single dose of 2500 mg/ kg body weight showed hyaline changes in some areas of cardiac myocytes with other areas showed faint dissolved nucleus of a prenecrotic stage (figure 1).

\section{Subacute toxicity study :}

It was noticed that ginger administration was not associated with any mortalities and abnormalities in general conditions, behavior, growth, and food and water consumption except for that the rats were calmer than their control rats.

\section{Blood pressure and heart rate}

There were no significant differences between the positive and negative control groups regarding blood pressure and heart rate $(\mathrm{P}>0.05)$ (table 2$)$ (figure 3$)$, so the negative control was used for comparison with ginger treated groups.

Comparison between the negative control group and group VI (received low dose of ginger $50 \mathrm{mg} / \mathrm{kg}$ ) revealed no significant difference regarding systolic and diastolic blood pressures ( $\mathrm{P}>0.05)$ and significant difference regarding the heart rate $(\mathrm{P}<0.01)$ (table 2), (figure 3).

Comparison between the negative control group and group VII (received high dose of ginger $500 \mathrm{mg} / \mathrm{kg}$ ) revealed significant difference between the two groups regarding all the measured parameters ( $\mathrm{P}<0.01$ - 0.0001) (table 2$)$, (figure 3 ).

Comparison between group VI and group VII revealed significant difference between the two groups regarding all the measured parameters ( $\mathrm{P}<0.01-0.0001)$ (table 3), (figure 3).

\section{Histopathologic results}

Longitudinal section of the left ventricle of the positive and negative control rats showed cardiac muscle fibers with acidophilic cytoplasm and centrally located nuclei with delicate connective tissue separating the cardiac myocyte fibers and 
capillaries in between. Longitudinal section of the left ventricle of rats treated with ginger in a dose of $50 \mathrm{mg} / \mathrm{kg}$ revealed waviness of myocardial fibers at the border of some fibers.

Longitudinal section of the left ventricle of ginger treated rats in a dose of $500 \mathrm{mg} /$ $\mathrm{kg}$ for 28 days showed cloudy swelling and granular cytoplasm, no capillaries were detected due to swelling of cells (figure 2).

\section{In- vitro study (on isolated rabbit aor-} tic strips):

Ginger at a concentration of $5 \mathrm{mg} / \mathrm{ml}$ produced a relaxant effect on rabbit's aortic strip pro- contracted with phenylephrine by $23 \pm 0.52 \%$ of the maximal contraction. Pre-incubation with L-NAME significantly attenuated the ginger- induced relaxation to be $9 \pm 0.49 \%$ of the maximum contraction induced by phenylephrine $(\mathrm{P}<0.0001)$ (table 4), (figure 4).

Pre- incubation with ginger significantly reduced the calcium chloride induced contraction of highly- depolarized aortic strip (by potassium) from $40.2 \pm 0.73 \mathrm{~mm}$ height to $33.38 \pm 0.7 \mathrm{~mm}$ with $18.43 \%$ reduction rate $(\mathrm{P}<0.0001)$ (table 5) (figure 5).

\section{DISCUSSION}

In the present study ginger in a single dose of $2500 \mathrm{mg} / \mathrm{kg}$ body weight pro- duced significant drop in both systolic and diastolic blood pressures and decrease in the heart rate when compared with their negative control rats. Ginger is a medicinal plant that has been widely used in Chinese, in treatment of hypertension (Ali et al., 2008). In a study of acute toxicity performed on hydro-alcoholic extract of ginger rhizome in mice, it was found that the drug was nontoxic up to a dose of 1500 $\mathrm{mg} / \mathrm{kg}$ body weight (Jagetia et al., 2004). In the heart rate context, remarkable bradycardia was found after oral administration of the ginger component, 6-shogaol in a dose of $70 \mathrm{mg} / \mathrm{kg}$ in mice (Suekawa et al., 1984). In the present acute toxicity study, the single dose of ginger produced hyaline changes in some areas of cardiac myocytes with other areas showed faint dissolved nuclei of a prenecrotic stage. It was reported that myocyte necrosis can result from ischemia that is followed by reperfusion (Schoen, 1999). After hypotension a post ischemic / reperfusion and reoxygenation state occur resulting in the production of Xanthene oxidase and $\mathrm{O}_{2}$ that generate superoxide radicals which result in extensive tissue damage (McCord and Roy, 1982).

In the present subacute toxicity study, ginger administration was not associated with any mortalities and abnormalities in general conditions, behavior, growth, and food and water consumption except for that the rats were calmer than their control 
rats. This was consistent with Rong et al. (2009) who administered ginger powder by oral gavage in doses of 500, 1000 and $2000 \mathrm{mg} / \mathrm{kg}$ for 35 days and reported nearly the same results.

In the present study administration of ginger in a dose of $50 \mathrm{mg} / \mathrm{kg}$ for 28 days produced no significant change in both systolic and diastolic blood pressures while it produced a significant decrease in heart rate when compared with the negative control rats. In a dose of $500 \mathrm{mg} / \mathrm{kg}$ for 28 days, ginger produced a significant drop in systolic and diastolic blood pressures and heart rate when compared with the negative control rats. The dose of 50 $\mathrm{mg} / \mathrm{kg}$ produced waviness of some myocardial fibers at their border in the cardiac tissue while $500 \mathrm{mg} / \mathrm{kg}$ produced cloudy swelling and granular cytoplasm, with disappearance of capillaries due to swelling of cells. These findings are parallel to that found by Schoen, (1999) who reported a waviness of myocardial fibers at the border in cases of myocardial ischemia.

Furthermore ginger is recommended by the traditional healers in South Asia for treatment of cases of cardio-myopathy, high blood pressure, palpitations and to improve the circulation for its use as a vasodilator (Kapoor, 1990; Duke, 2002).

Pharmacological studies were performed on (6)-gingerol and (6)-shogaol which are the pungent constituents of ginger (Zingiber Officinale Roscoe). In the cardiovascular system, both constituents produced depressor response at doses of $70 \mathrm{mg} / \mathrm{kg}$ on the blood pressure of rats (Suekawa et al., 1984).

In hypertensive animals, ginger has a generally dose-dependent hypotensive effect, in addition ginger caused vasodilatation in rats and rabbits following induced vasoconstriction, and exhibited calcium channel-blocking activity similar to verapamil (Ghayur and Gilani, 2005b). The only human trial to address hypertension, found a synergistic effect between ginger and nifedipine (Young et al., 2006).

The in-vitro experiments revealed that ginger is a partial vaso- relaxant in a concentration of $5 \mathrm{mg} / \mathrm{ml}$ as it produced a relaxant effect on rabbit's aortic strip procontracted with phenylephrine. While preincubation with L-NAME significantly attenuated the ginger- induced relaxation indicating that the vasodilator effect of ginger is partially mediated through nitric oxide synthesis or release. L- nitro- arginine methyl ester (L- NAME) is a nitric oxide synthase inhibitor (Colas et al., 2000). These results are consistent with those of Ghayur et al., (2005) who reported that ginger induced a dose-dependent (3-10 $\mathrm{mg} / \mathrm{kg}$ ) fall in the arterial blood pressure (BP) of anaesthetized rats which was partially blocked by atropine $(1 \mathrm{mg} / \mathrm{kg})$. 
Cholinergic compounds are known to cause a fall in BP by activation of muscarinic receptors located on the endothelium of blood vessels and the cholinergic receptor mediated vasodilatation is due to release of NO from the endothelium (Furchgott and Zawadski, 1980) and consequent increase of cGMP contents in the vascular smooth muscles in response to activation of guanylyl cyclase (Andreopoulos and Papapetropoulos, 2000). The bradycardic effect of ginger may be partially due to the antimuscarenic effect of ginger as evidenced by (Gilani and Cobbin, 1986) who found that ginger produced a partial blockade with atropine which is a competitive muscarenic antagonist.

This study revealed that Pre- incubation of the rabbit's aortic strip with ginger significantly reduced the calcium chloride induced contraction of highly- depolarized aortic strip. This demonstrated that ginger has a calcium channel blocking effect as revealed by (Ghayur and Giliani, 2006). These results are parallel to those of (Bolton, 1979; Mecca and Love, 1992) who reported that a vasodilator component mediated by the aqueous ginger extract was due to calcium channel blockade, as it relaxed the high $\mathrm{K}^{+}$- induced contractions specifically as well as shifted the $\mathrm{Ca}^{2+}$ dose-response curves to the right as reported by (Godfraind et al., 1986; Karaki et al., 1997).

\section{CONCLUSION}

A single dose of ginger in a dose 5 times the high dose $(2500 \mathrm{mg} / \mathrm{kg}$ ) can be toxic by causing severe hypotension and bradycardia with induction of hyaline changes and fainting of some nuclei in cardiac myocyte fibers of a pre- necrotic stage. Administration of ginger to rats for 28 days in the low dose (50 mg/ kg) produced bradycardia with waviness of some cardiac muscle fibers. Ginger in a high dose (500 mg/ kg) for 28 days, produced both hypotension and bradycardia with degenerative changes in cardiac myocyte fibers. The hypotensive and bradycardic effects of ginger may partially, be due to induction of vasodilatation by increasing nitric oxide release or synthesis and partially due to a calcium channel blocking effect. Also, a cholinomimetic effect could be contributed in the cardiovascular effects of ginger.

\section{RECOMMENDATIONS}

As ginger is a hypotensive and bradycardic medication at high doses, it must be used with caution in normal non- hypertensive persons. Further studies must be carried out to detect other effects of different doses of ginger on other systems in the body. Further studies on humans must be carried out to detect how it can be effective in the treatment of cases of hypertension and tachycardia. 


\section{ACKNOWLEDGMENT}

We would like to express our deep gratitude and sincere appreciation to Prof. Dr. Mona Mohammad El- Sayed,
Assistant Professor of Pathology, Faculty of Medicine, Zagazig University for her great help and support in illustrating the histopathological results of the study. 
Table (1): Statistical comparison between the means of systolic blood pressure (SBP), diastolic blood pressure (DBP) and heart rate (HR) of positive and negative control rats and ginger treated rats received $2500 \mathrm{mg} / \mathrm{kg} \mathrm{BW}$," An acute toxicity study".

\begin{tabular}{|c|c|c|c|}
\hline \multirow[t]{2}{*}{ Parameter } & \multicolumn{2}{|c|}{$\begin{array}{c}\text { Mean } \pm \text { SD } \\
(n=6)\end{array}$} & $\begin{array}{l}\text { Mean } \pm \text { SD } \\
(n=6)\end{array}$ \\
\hline & +ve control & -ve control & Ginger \\
\hline \multirow[t]{2}{*}{ SBP mmHg } & $114.35 \pm 4.05$ & $115.2 \pm 3.04$ & $75.55 \pm 1.31$ \\
\hline & \multicolumn{2}{|c|}{$\begin{array}{c}\text { Paired-t } 1.57 \\
\mathrm{P}>0.05\end{array}$} & $\begin{array}{c}29.14^{*} \\
\mathrm{P}<0.0001\end{array}$ \\
\hline \multirow[t]{2}{*}{ DBP mmHg } & $73.88 \pm 2.82$ & $73.62 \pm 3.01$ & $44.9 \pm 1.69$ \\
\hline & $\begin{array}{c}\text { Paired-t } 1.57 \\
\mathrm{P}>0.05\end{array}$ & & \begin{tabular}{c|c} 
& $44.9 \pm 1.69$ \\
$37.46^{*}$ \\
$\mathrm{P}<0.0001$
\end{tabular} \\
\hline \multirow[t]{2}{*}{ HR beat/ minute } & $293.37 \pm 2.5$ & $293.83 \pm 2.81$ & $192.73 \pm 1.1$ \\
\hline & $\begin{array}{c}\text { Paired-t } 0.7 \\
\mathrm{P}>0.05\end{array}$ & & $\begin{array}{c}81.72^{*} \\
\mathrm{P}<0.0001\end{array}$ \\
\hline
\end{tabular}

Table(2): Statistical comparison between the means of systolic blood pressure (SBP), diastolic blood pressure (DBP) and heart rate (HR) of positive and negative control rats, the low dose $(50 \mathrm{mg} / \mathrm{kg})$ of ginger treated rats and the high dose $(500 \mathrm{mg} / \mathrm{kg})$ of ginger treated rats, "a subacute toxicity study for 28 days".

\begin{tabular}{|c|c|c|c|c|c|}
\hline \multirow[t]{2}{*}{ Parameter } & \multicolumn{2}{|c|}{$\begin{array}{c}\text { Mean } \pm \text { SD } \\
(n=6)\end{array}$} & $\begin{array}{l}\text { Mean } \pm \text { SD } \\
(n=6)\end{array}$ & \multicolumn{2}{|c|}{$\begin{array}{c}\text { Mean } \pm \text { SD } \\
(n=6)\end{array}$} \\
\hline & + ve control & -ve control & Ginger $50 \mathrm{mg} / \mathrm{kg}$ & -ve control & $\begin{array}{l}\text { Ginger } 500 \\
\mathrm{mg} / \mathrm{kg}\end{array}$ \\
\hline \multirow[t]{2}{*}{ SBP mmHg } & $109.62 \pm 2.96$ & $109.6 \pm 2.83$ & $110.82 \pm 2.49$ & $109.6 \pm 2.83$ & $103.43 \pm 0.95$ \\
\hline & \multicolumn{2}{|c|}{$\begin{array}{l}\text { Paired- t } 0.11 \\
\quad P>0.05\end{array}$} & $\begin{array}{l}\text { Paired- t } 0.89 \\
\quad \mathrm{P}>0.05\end{array}$ & \multicolumn{2}{|c|}{$\begin{array}{c}4.28^{*} \\
\mathrm{P}<0.01\end{array}$} \\
\hline \multirow[t]{2}{*}{ DBP mmHg } & $73.9 \pm 1.81$ & $75.1 \pm 2.17$ & $73.58 \pm 2.58$ & $75.1 \pm 2.17$ & $62.23 \pm 0.72$ \\
\hline & \multicolumn{2}{|c|}{$\begin{array}{c}\text { Paired- t } 1.87 \\
\mathrm{P}>0.05\end{array}$} & $\begin{array}{l}\text { Paired- t } 1.1 \\
\quad \mathrm{P}>0.05\end{array}$ & \multicolumn{2}{|c|}{$\begin{array}{c}12.58^{*} \\
\mathrm{P}<0.0001 \\
\end{array}$} \\
\hline \multirow{2}{*}{$\begin{array}{l}\text { HR beat/ } \\
\text { minute }\end{array}$} & $293.87 \pm 2.18$ & $294.3 \pm 3.07$ & $273.93 \pm 8.81$ & $294.3 \pm 3.07$ & $255.73 \pm 1.6$ \\
\hline & \multicolumn{2}{|c|}{$\begin{array}{c}\text { Paired- t } 0.3 \\
\mathrm{P}>0.05\end{array}$} & $\begin{array}{l}\text { Paired- t } 5.05^{*} \\
\quad \mathrm{P}<0.01\end{array}$ & \multicolumn{2}{|c|}{$\begin{array}{c}24.23 * \\
\mathrm{P}<0.0001\end{array}$} \\
\hline
\end{tabular}


Table (3): Statistical comparison between the means of systolic blood pressure (SBP), diastolic blood pressure (DBP) and heart rate (HR) of the low therapeutic dose of ginger treated rats and the high therapeutic dose of ginger treated rats, "a subacute toxicity study for 28 days".

\begin{tabular}{|c|c|c|}
\hline \multirow[t]{2}{*}{ Parameter } & \multicolumn{2}{|c|}{$\begin{array}{c}\text { Mean } \pm \text { SD } \\
(n=6)\end{array}$} \\
\hline & Ginger $50 \mathrm{mg} / \mathrm{kg}$ & Ginger $500 \mathrm{mg} / \mathrm{kg}$ \\
\hline \multirow[t]{2}{*}{ SBP mmHg } & $110.82 \pm 2.49$ & $103.43 \pm 0.95$ \\
\hline & \multicolumn{2}{|c|}{$\begin{array}{c}\text { Paired-t 7.34* } \\
\mathrm{P}<0.001\end{array}$} \\
\hline \multirow[t]{2}{*}{ DBP mmHg } & $73.58 \pm 2.58$ & $62.23 \pm 0.72$ \\
\hline & \multicolumn{2}{|c|}{$\begin{array}{c}\text { Paired-t } 11.93 * \\
\mathrm{P}<0.0001\end{array}$} \\
\hline \multirow[t]{2}{*}{ HR beat/ minute } & $273.93 \pm 8.81$ & $255.73 \pm 1.6$ \\
\hline & \multicolumn{2}{|c|}{$\begin{array}{l}5.19 * \text { Paired-t } \\
\mathrm{P}<0.01\end{array}$} \\
\hline
\end{tabular}

Table (4): The relaxant effect of ginger $5 \mathrm{mg} / \mathrm{ml}$ on isolated rabbit aortic strip procontracted with phenylephrine $(10 \mu \mathrm{g} / \mathrm{ml})$ in absence and presence of LNAME $(100 \mu \mathrm{M})$.

\begin{tabular}{|c|c|c|}
\hline \multicolumn{3}{|c|}{ Percent of reduction in phenylephrine induced maximal contraction } \\
$\mathrm{n}=6$
\end{tabular}

Table (5): Effect of ginger $5 \mathrm{mg} / \mathrm{ml}$ on calcium chloride $(1 \mathrm{mM})$ induced contraction of highly- depolarized rabbit aortic strip produced by $60 \mathrm{mM}$ of $\mathrm{K}^{+}$.

\begin{tabular}{|c|c|c|c|}
\hline \multicolumn{3}{|c|}{ Height of contraction induced by calcium chloride } \\
\hline \multirow{3}{*}{$\begin{array}{c}\text { Ginger } \\
5 \mathrm{mg} / \mathrm{ml}\end{array}$} & In absence of ginger & In presence of ginger & \multirow{2}{*}{$\%$ of reduction } \\
\cline { 2 - 3 } & Mean \pm SD $(\mathrm{mm})$ & Mean \pm SD $(\mathrm{mm})$ & \\
\cline { 2 - 3 } & $40.2 \pm 0.73$ & $33.38 \pm 0.7$ & \multirow{2}{*}{18.43} \\
\hline & $\begin{array}{c}\text { Paired- t: } 14.37^{*} \\
\text { Significance: }<0.0001\end{array}$ \\
\hline
\end{tabular}




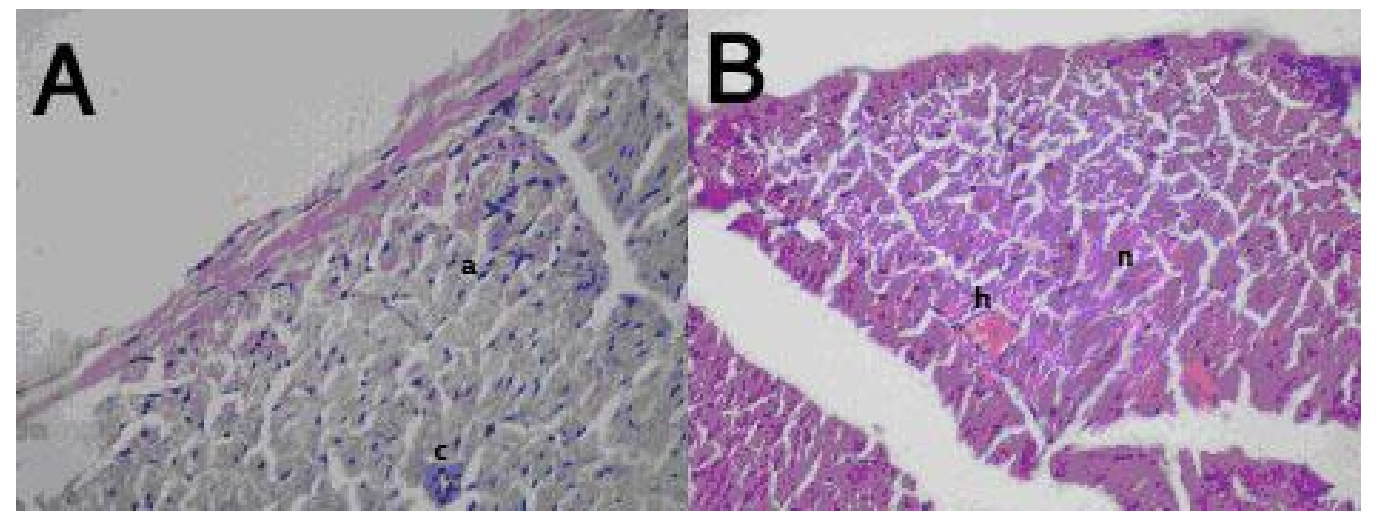

Fig. (1) : Two photomicrographs (PMs). PM- A transverse section of the left ventricle of a control rat showing cardiac muscle fibers with acidophilic cytoplasm and centrally located nuclei (a) with capillaries in between (c). PM- B, transverse section of the left ventricle of ginger treated rats in a single dose of $2500 \mathrm{mg} / \mathrm{kg}$ showed hyaline change $(\mathrm{h})$ in some areas. Some areas of the cardiac myocytes showed faint dissolved nucleus of a prenecrotic stage $(\mathrm{n})$.

(H \& E X 400)

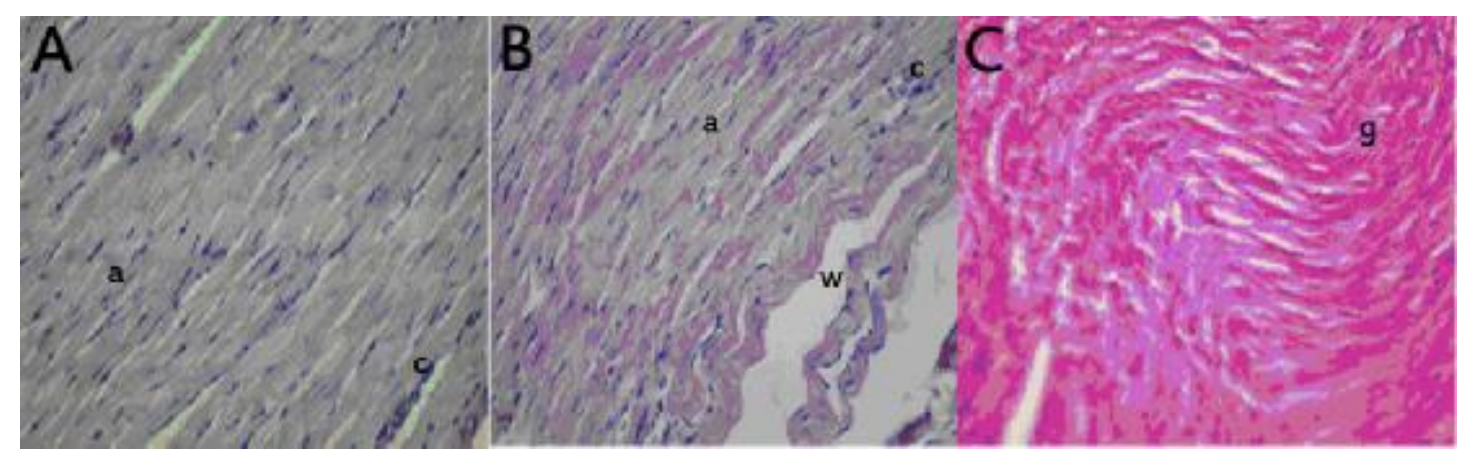

Fig. (2) : Three photomicrographs (PMs). PM- A, longitudinal section of the left ventricle of a negative control rat showing cardiac muscle fibers with acidophilic cytoplasm and centrally located nuclei (a) and capillaries in between (c). PM- B, longitudinal section of the left ventricle of a rat received ginger in a dose of $50 \mathrm{mg} / \mathrm{kg}$ for 28 days showing centrally located nuclei (a) and waviness of some myocardial fibers at their border (w). PM- C, of a ginger treated rat in a dose of $500 \mathrm{mg} / \mathrm{kg}$ for 28 days showed cloudy swelling and granular cytoplasm (g), no capillaries detected due to swelling of cells.

( $\mathrm{H} \& \mathrm{E} X 400)$ 


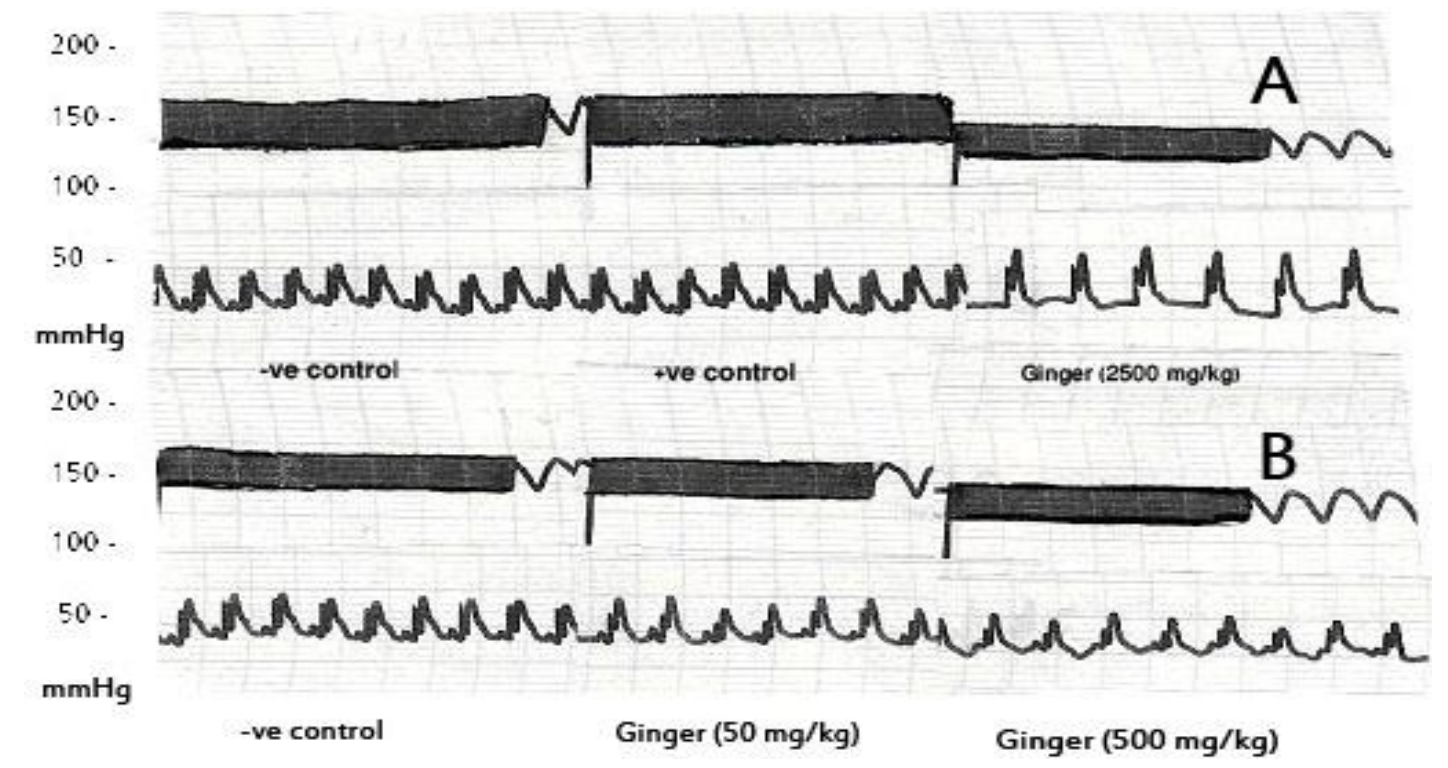

Fig. (3) : Effect of Ginger on the arterial blood pressure and heart rate of rats; an acute toxicity study (A) and subacute toxicity study (B).

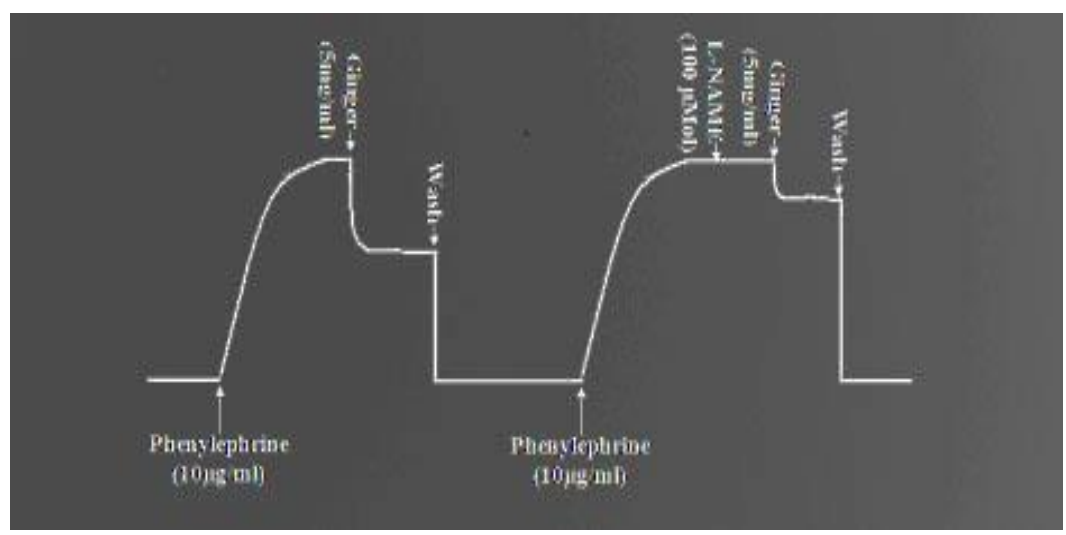

Fig. (4) : The relaxant effect of ginger on isolated rabbit's aortic spiral strips procontracted with phenylephrine in absence and in presence of L-NAME.

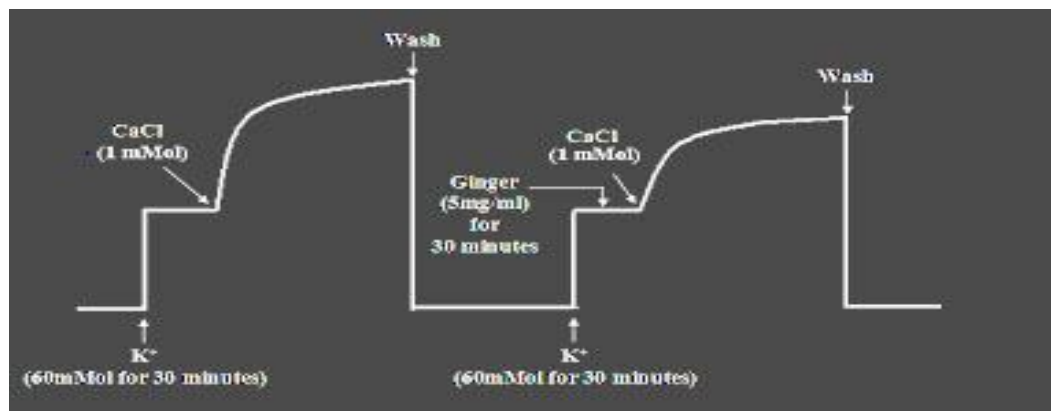

Fig. (5) : Effect of ginger on calcium chloride- induced contractions of highly depolarized rabbit's aortic spiral strips produced by $\mathrm{K}+$. 


\section{REFERENCES}

Ahmed, R. S.; Seth V; Pasha, S. T. and Banerje, B. D. (2000) : "Influence of dietary ginger (Zingibar officinal Rosc.) on oxidative stress induced by malathion in rats". Food Chem. Toxicol., 38 (5): 443450.

Al-Amin, Z. M.; Thomson, M.; AlQattan, K. K.; Peltonen- Shalaby, R. and Ali, M. (2006) : "Antidiabetic and hypolipidemic properties of ginger (Zingiber officinale) in streptozotocin- induced diabetic rats". Br. J. Nutr., 96 (4): 660- 666.

Ali, B. H.; Blunden, G.; Tanira, M. O. and Nemmar, A. (2008) : "The use of ginger (Zingiber officinal Rosc.) as potential anti-inflammatory and antithrombotic agent". Food Chem. Toxicol., 46 (2): 409420.

\section{Andreopoulos, S. and Papapetropou-} los, A. (2000): "Molecular aspects of soluble guanylyl cyclase regulation". Gen. Pharmacol., 34: 147-157.

Bean, P. (2002) : "The use of alternative medicine in the treatment of hepatitis C". Am. Clin. Lab., 21 (4): 19- 21.

Bolton, T. B. (1979) : "Mechanism of action of transmitters and other substances on smooth muscles". Physio. Rev., 59: 606-718.
Borrelli, F.; Capasso, R.; Aviello, G.; Pittler, M. H. and Izzo, A. A. (2005) : "Effectiveness and safety of ginger in the treatment of pregnancy-induced nausea and vomiting". Obstet. Gynecol., 105 : 849856.

Burden, D. T.; Blaber, L. C. and Natoff, I. L. (1979) : "A simple method for recording left ventricular pressure and heart rate in cat". Pharmacol. Ther., $5: 99-102$.

Chiang, H. M.; Chao, P. D.; Wen, K. C.; Tsai, S. Y. and Hou, Y. C. (2006) : "Ginger significantly decreased the oral bioavailability of cyclosporine in rats". Am. J. Clin. Med., 34 (5): 845- 855.

Colas, B.; Slama, M.; Collin, T.; Safar. M. and Andrejac, M. (2000) : "Mechanisms of methyclothiazide- induced inhibition of contractile response in rat aorta". Eur. J. pharmacol., 408: 63- 67.

Duke, J. A. (2002) : Handbook of Medicinal Herbs., CRC Press, Boca Raton, FL, P.P. 327-329.

Durham, H. D.; Comeau, A. M.; Cameron. P. H. and Ecobichon, D. J. (1982) : "Subacute toxicity in rats of orally administered fenitrothion alone and in a selected formulation". Toxicology and Applied Pharmacology, 62 (3): 455- 464.

Furchgott, R. F. (1960) : "Spiral cut 
strips of rabbit aorta for in- vitro studies of responses of arterial smooth muscles". Methods Med. Res., 8: 177- 186.

Furchgott, R. F. and Zawadski, J. V. (1980) : "The obligatory role of endothelial cells in the relaxation of arterial smooth muscle by acetylcholine". Nature, 299:373376.

Gay, W. I. (1965) : Methods of Animal Experimentation. 2nd ed., Academic Press, New York and London.

Ghayur, M. N. and Gilani, A. H (2005a) : " Pharmacologial basis for the medicinal use of ginger in gastrointestinal disorders". Dig. Dis. Sci., 50 (10): 18891897.

Ghayur, M. N. and Gilani, A. H. (2005b) : "Ginger lowers blood pressure through blockade of voltage-dependent calcium channels". Cardiovasc Pharmacol., 45 (1): 74-80.

Ghayur, M. N. and Gilani, A. H. (2006) : "Species differences in the prokinetic effects of ginger". Int. J. Food Sci. Nutr., 57 (1-2): 65- 73.

Ghayur, N. M.; Gilani, H. N.; Afridi, B. M. and Houghton, J. P. (2005) : "Cardiovascular effects of ginger aqueous extract and its phenolic constituents are mediated through multiple pathways". Vascular
Pharmacology, 43 (4): 234-241.

Ghosh, M. N. (1971) : Fundamentals of Experimental Pharmacology. 1st ed., Scientific Book Agency, Calcutta, P.P.233235.

Gilani, A. H. and Cobbin, L. B. (1986) : "Cardioselectivity of himbacine: a muscarinic receptor antagonist". NaunynSchmiedeberg's Arch. Pharmacol., 332: 620.

Godfraind, T.; Miller, R. and Wibo. M. (1986) : "Calcium antagonism and calcium entry blockade". Pharmacol. Rev., 38 : 321416.

Horobin, R. W. and Bancroft, J. D. (1998) : Haematoxyline and Eosin As An Overnight Stain. In: Troubleshooting Histology Stains. $1^{\text {st }}$ ed., Churchill Livingstone Professional Limited Press. Edinburgh, Scotland, London, UK, New York : P.P. 88- 89.

Jagetia, G.; Baliga, M. and Venkatesh, P. (2004) : "Ginger (Zingiber officinale Ros.), a dietary supplement, protects mice against radiation- induced lethality: mechanism of action". Cancer Biother Radiopharm; 19 (4): 422-435.

Kapoor, L. D. (1990) : Handbook of Ayurvedic Medicinal Plants, CRC Press, Boca Raton, FL, P.P. 341-342. 
Karaki, H. H.; Ozaki, M.; Hori, M.; Mitsui-Saito, K.; Amano, K..; Harada, S.; Miyamoto, H.; Nakazawa, K. J.; et al. (1997) : "Calcium movements, distribution, and functions in smooth muscle". Pharmacol. Rev., 49: 157-230.

McCord, J. M. and Roy, R. S. (1982) : "The pathophysiology of superoxide:roles in inflammation and schemia". Can J Physiol Pharmacol., 60 (11): 1346- 1352.

Mecca, T. E. and Love, S. D. (1992) : "Comparative cardiovascular actions of clentiazem, diltiazem, verapamil, nifedipine, and nimodipine in isolated rabbit tissues". J. Cardiovasc. Pharmacol., 20 : 678682.

Nagahushan, M.; Amonkar, A. J. and Bhide, S. V. (1987) : " Mutagenicity of gingerol shogoal and antimutagenicity of Zingerone in Salmonella/ microsome assay". Cancer Lett., 36 (2): 21-33.

NRC, (1996): National Research Council, Guide for the Care and Use of Laboratory Animals, National Academy Press, Washington, D.C., P.P. 1-7.

Padma, V. V.; Christie, A. D. and Ramkuma, K. M. (2007) : "Induction of Apoptosis by ginger in HEP-2 cell line is mediated by reactive oxygen species". Basic Clin. Pharmacol. Toxicol., 100 (5): 302307.
Rong, X.; Peng, G.; Suzuki, T.; Yang, Q.; Yamahara, J. and Li, Y. (2009) : "A 35-day gavage safety assessment of ginger in rats". Regul Toxicol Pharmacol., $54(2)$ : 118-123.

Schoen, F. J. (1999) : The heart. In : Robbins and Cotran Pathologic Basis of Disease. Kumar, V.; Abbas, A. K. and Fausto N (Eds.), 7th ed. W. B. Saunders Co, New York, P.P. 555- 612.

Sheridan, J. (2009) : SPSS - Analysis Without Anguish Using SPSS Version 17.0 for Windows + SPSS Version 17 Student Software; 15 October, John Wiley \& Sons Australia Ltd, ISBN : 9781742165639: 320.

Shingategri, V. M.; Venkatesha, U.; Ranvir, R. K.; Chaudhari, G. R.; et al. (2002) : Subacute toxicity of RBx 7644 by oral route in rats. Conference on Antimicrobial Agents and Chemotherapy 42nd: San Diego, Calif.

Suekawa, M.; Ishige, A.; Yuasa, K.; Sudo, K.; Aburada, M. and Hisoya, E. (1984) : "Pharmacological studies on ginger. I. Pharmacological actions of pungent constituents, (6)- gingerol and (6)- shagol". J. Pharmacobiodyn., 7 (11): 836- 848.

Thomson, M.; Al- Qattan, K.; AlSaman, M.; Alnaqeeb, M. M.; Khan, I. and Ali, M. (2002) : "The use of ginger 
(Zingiber officinal Rosc.) as potential antiinflammatory and antithrombotic agent". Prostaglandines, Leukot. Essent. Fatty Acids; 67 (6): 457- 478.

Weinder, M. S. and Sigwart, K. (2001) : "Investigation of the teratogenic potential of zingibar officinale extract in the rat". Reprod. Toxicol., 15 (1): 75- 80.

Wilkinson, J. M. (2000) : "Effect of ginger tea on the fetal development of Sprague- Dawley rats". Reprod. Toxicol., 14(6): 507- 512.
Yemitan, O. K. and Izegbu, M. C. (2006) : "Protective effects of Zingiber officinale (Zingiberaceae) against carbon tetrachloride and acetaminophen- induced hepatotoxicity in rats". Phytother. Res., 20 (11): 997- 1002.

Young, H. Y.; Liao, J. C.; Chang, Y. S.; Luo, Y. L, Lu, M. C. and Peng, W. H. (2006): "Synergistic effect of ginger and nifedipine on human platelet aggregation: a study in hypertensive patients and normal volunteers". Am. J. Chin. Med., 34 (4): 545551. 


\title{
دراسة التأثير السهى للزنجبيل على القلب والجهاز الدورى فى الجرذان البيضاء

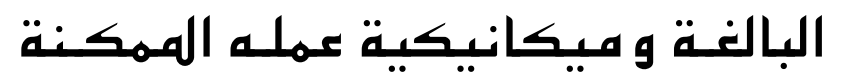

\author{
المشتركون فى البحث

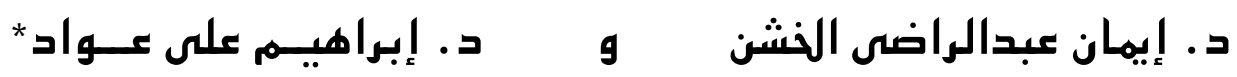 \\ * من قسمى الطب الشـرعى والسموم الإكلينيكية والفارماكولويىى \\ كليـة الطب - جامعــة الزقازيستق
}

للزنجبيل فوائـد طبية كثيرة منها أنه يستخدم فى تسكين آلام البطن ومضاد للتقيؤ وكذلك مخفض للضغط، إستهدف هذا البحث دراسة التأثير السمى للزنجبيل على القلب وبلعض قياسات الجهـاز الدورى فى الجرذان البيضاء البالغة وميكانيكية عمله الممكنة، أستخدم فى هذا البحث ع^ جرذاً أبيض بالغاً قسمت على دراستين، الأولى وبها ب جرذاً مقسمة إلى ع مجموعات كل منها با جرذ لدراسة التأثير تحت الحاد للزنجبيل لمدة YA يوماً بإعطاء جرعة مخفضة من العقار تبلغ . همجم/كجم يومياً بالفم، وكان لكل دراسة مجموعتين ضابتتين إحداهما لاتأخذ غير الطعـام والشراب العاديين (المجموعـة الضابطة السالبة) ، والأخرى تعطى محلول ملحى متعادل بالفم الذى أستخدم كحامل للزنجبيل (المجموعة الضابطة الموجبة) ، بعد ع r ساعة من الدراسة الأولى و Y يوماً من الدراسة الثانية تم قياس الضغط وعمل رسم قلب لعدد 7 جرذان من كل مجموعة، وتم ذبح الست جرذان الأخرى من كل مجموعة وأخذ عينات من القلب لفحصها بالمجهر العادى بعد تجهيزها لذلك، دراسة ميكانيكية عمل الزنجبيل تم باستخدام 1 من الأرانب البلدى وأخذ جزئين من الشريان الأورطى من هذه الأرانب، أثبت البحث أن للزنجبيل أثر مثبط على الضغط ومعدل ضربات القلب ذو دلالة إحصائية عالية فى الدراسة الحادة وبالجرعة العالية فى الدراسة تحت الحادة، وكذلك أدى العقار إلى إحداث تغيرات باثولوجية على القلب مثل ضمور نواة بعض الخلايا وانتفاخ بعض الخلايا الأخرى، كان للزنجبيل أثراً مثبطاً لانقباض عضلة الشريان الأورطى المعزولة ذو دلالة إحصائية عالية بعد حقنها بـ L-NAME ، وكذلك تأثير مثبط ذو دلالة إحصائية عالية لزيادة إنقباض عضلة الشريان الأورطى المحدثة بالكالسيوم كلورايد. 
يستخلص من هذا البحث أن للزنجبيل تأثير مخفض لضغط الدم يختلف باختلاف الجرعة المعطاة والذى من الممكن أن يكون مصاحباً لبعض التغيرات الباثولوجية لعضلة القلب، وأن التأثير المثبط لضغط الدم من الممكن أن يكون بسبب التأثير المثابه لعمل الجهاز العصبى السمبتاوى جزئياً وكذلك تأثيراً مغلقاً لقنوات الكالسيوم وأكسيد النيتريك، بناء على هذا البحث يوصى باستخدام الزنجبيل بصورة مقننة فى الإنسان ودراسة تأثيراته على الأجهزة المختلفة الأخرى وعمل دراسات أخرى لإثبات فاعليته كمخفض لضغط الدم فى الإنسان. 